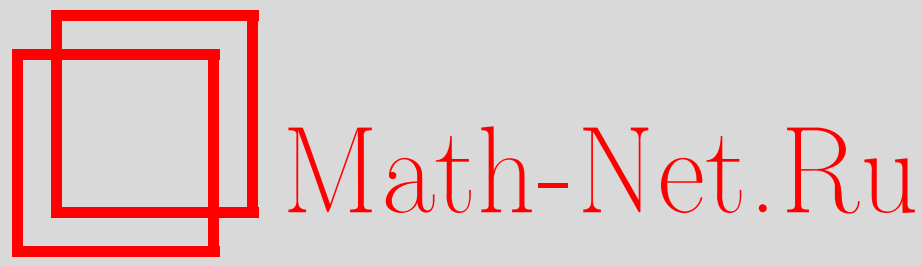

Памяти Альберта Никифоровича Тавхелидзе, ТМФ, 2010, том 165, номер 3, 387-388

DOI: https://doi.org/10.4213/tmf6584

Использование Общероссийского математического портала Math-Net.Ru подразумевает, что вы прочитали и согласны с пользовательским соглашением http://www . mathnet.ru/rus/agreement

Параметры загрузки:

IP : 54.157 .27 .8

26 апреля 2023 г., 12:50:29

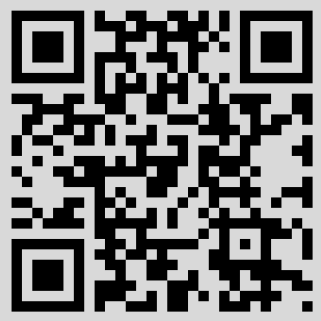




\section{ПАМЯТИ АЛЬБЕРТА НИКИФОРОВИЧА ТАВХЕЛИДЗЕ}

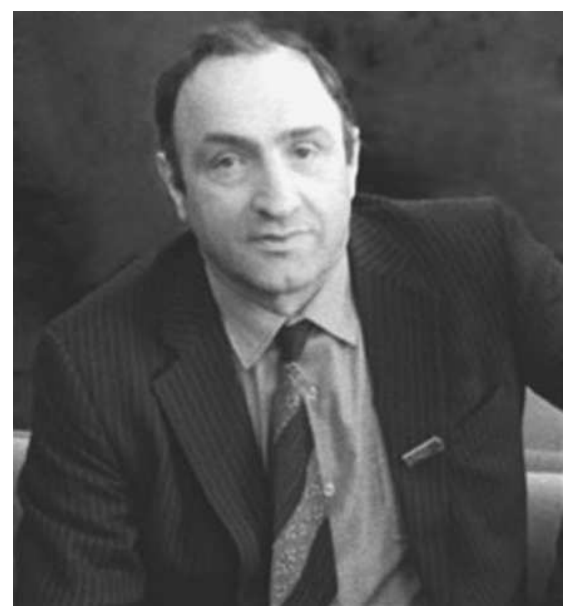

16 декабря 2010 года исполняется 80 лет со дня рождения академика Альберта Никифорович Тавхелидзе (16.12.1930-27.02.2010) - выдающегося физика-теоретика, с именем которого неразрывно связаны не только новые направления фундаментальной науки, но и целые научные школы и центры, сформированные его усилиями в Грузии, России и Украине.

А. Н. Тавхелидзе - один из создателей журнала "Теоретическая и математическая физика", он во многом определил его научную направленность, будучи более 20 лет заместителем главного редактора журнала.

Альберт Никифорович Тавхелидзе родился 16 декабря 1930 года в столице Грузии, г. Тбилиси. В 1953 году он окончил физический факультет Тбилисского государственного университета. Дальнейшее становление его как физика-теоретика происходило под руководством Н. Н. Боголюбова в Москве, в аспирантуре Математического института им. В. А. Стеклова АН СССР. В 1956 году, защитив кандидатскую диссертацию, посвященную фоторождению пионов на нуклонах, Тавхелидзе начинает работать в Дубне, в Объединенном институте ядерных исследований (ОИЯИ). В этом институте он проходит путь от научного сотрудника до заместителя директора Лаборатории теоретической физики. При его активном участии развивается международное сотрудничество и происходит формирование научной политики ОИЯИ.

Альберт Никифорович Тавхелидзе - один из первооткрывателей нового квантового числа кварков "цвета" и создателей динамической кварковой модели адронов.

Его научные интересы всегда были очень широки, они включали в себя практически всю физику элементарных частиц и квантовую теорию поля. Им получен ряд фундаментальных результатов, среди которых дисперсионные соотношения и квазипотенциальный метод в квантовой теории поля, конечно-энергетические правила сумм и дуальность. Ему принадлежит открытие связи явления спонтанного нарушения симметрии с происхождением масс фермионов, формулировка правил "кваркового счета", вывод соотношения между структурой основного состояния и несохранением фермионного и барионного чисел в калибровочных теориях. 
Альберт Никифорович Тавхелидзе вырастил плеяду ученых мирового уровня, многие из которых являются действительными членами РАН и академий других стран. Он принимал активное участие в создании и стал первым директором Института ядерных исследований РАН. В 2008 году Альберт Никифорович основал новую кафедру Физики частиц и космологии на Физическом факультете Московского государственного университета. В Грузии им были созданы Институт физики высоких энергий при Тбилисском университете и Отдел теоретической физики в Институте математики АН Грузии. Вместе с Н. Н. Боголюбовым он сыграл ключевую роль в создании Института теоретической физики АН Украины.

А.Н. Тавхелидзе - инициатор и организатор ряда крупных, ставших регулярными, международных конференций, среди которых Международная конференция по математическим проблемам квантовой теории поля и квантовой статистики и Международная конференция "Кварки".

В течение 20 лет Тавхелидзе был Президентом АН Грузии и много сделал для усиления роли Академии наук в научной и интеллектуальной жизни Грузии.

Альберт Никифорович Тавхелидзе - иностранный член ряда Академий наук, награжден высшими научными и государственными наградами СCCР, Грузии и Российской Федерации. В их числе Государственная премия СССР 1973 года за цикл работ "Фоторождение пи-мезонов на нуклонах", Ленинская премия 1988 года за цикл совместных исследований "Новое квантовое число "цвет" и установление динамических закономерностей в кварковой структуре элементарных частиц и атомных ядер", Государственная премия Российской Федерации за 1998 год "за создание Баксанской нейтринной обсерватории и исследования в области нейтринной астрофизики элементарных частиц и космических лучей" и премия Правительства РФ 2001 года “За разработку, создание и ввод в научную эксплуатацию сильноточного линейного ускорителя протонов Московской мезонной фабрики". В 1987 году в Государственном реестре открытий СССР было зарегистрировано открытие "Правила кваркового счета Матвеева-Мурадяна-Тавхелидзе". Национальная академия наук Украины в 1996 году присудила А. Н. Тавхелидзе премию им. Н. Н. Боголюбова, а в 1998 году он награжден золотой медалью Международной ассоциации академий наук за большой вклад, внесенный в укрепление международного научного сотрудничества.

Альберт Никифорович был беззаветно предан науке, он всегда отличался редкой целеустремленностью и работоспособностью, умением сплотить людей для решения масштабных задач. Он был требователен к себе и коллегам в работе и в то же время оставался добрым и отзывчивым человеком.

Светлый образ этого замечательного ученого и человека навсегда останется в памяти знавших его людей.

Редакционная коллегия журнала ТМФ 